\title{
Optimizing fish structure in angling ponds focusing on white fish
}

\author{
József Molnár - Balázs Csorbai - Gergely Bernáth - Levente Várkonyi - Béla Urbányi - Zoltán Bokor \\ Szent István University, Department of Aquaculture, Gödöllö \\ Molnar.Jozsef@mkk.szie.hu
}

\section{SUMMARY}

According to new amendments of laws, commercial fishing licenses of natural waters shall not be issued from the calendar year 2016 in Hungary. However, the most settlement of white fish to angler ponds originated from natural waters. Currently, there is no sufficient quantity of fish species belonging to this group available to fulfil the settlement commitments of fish farmers. The aim of this recent study is to develop a breeding and production technology that is suitable for settlement of large quantities of this fish species of appropriate length of (4-5 cm). The following methods are investigated: aquaculture cage system (pond-in-pond system), monoculture and mixed population with different ratio of white fish in fish structure. Due to the different environmental needs of different fish species, many parameters need to be investigated, for example: stocking density, feeding, oxygen level, monoculture or mixed populations, growth potential and mortality. A preliminary experiment was carried out following the artificial propagation of ide (Leuciscus idus) following a 21-day larval rearing experiment in which the effect of different stoking density was investigated for mortality and growth. On the basis of the expected results, the optimal conditions for the aquaculture cage system will be described, regarding to the white fish stock.

Keywords: white fish, fish structure, fish farming, fish rearing

\section{INTRODUCTION}

Farmers of angler-treated waters have been compensated for the fish that are needed from natural water for the optimal fish structure of their waters. The following paragraph 8 is added to Article 74: "(8) Commercial fishing licenses shall of natural waters not be issued for the calendar year 2016 and the subsequent calendar years."

As a new emerging demand in the sector, the rearing of cyprinids for example bream species, asp (Aspius aspius) in pond farming conditions. Some of these species do not yet have the elaborate propagation method. To this end, new production and technological developments are needed as pond fish production is currently unable to produce the sudden increase in demand.

So far, fishermen did not consider the bream valuable, they seen them as a by-product. Accordingly, they did not really deal with the propagation of bream. They thought it was more economic damage, increased fishing costs, did not consider their breeding and sales relevant. The needs of fishermen and anglers have basically uncorrelated from the fish species. However, today's supply and demand conditions have changed.

The lack of the settleable (white fish with minimum length of 4-5 cm) bream means large issue to the head of the angling ponds in several aspects.

The carp (Cyprinus carpio) alone cannot fully utilize the biological production of fish ponds. To achieve this, it is also necessary to stock other species of fish, which, due to the different nutritional needs, can produce much higher fish production. In waters with different ecosystem, different species of fish find their ideal habitat.

Bream and specific cyprinids are popular prey to anglers, in addition for predatory fish means primary feed.
There are currently no adequate quantities of whitefish available for the head of the angling ponds, so the market price has begun to increase. It has now reached the level where it is worthwhile to breed these species under pond farming conditions. In addition, the number of anglers has grown steadily over the years, leading to an increase in catch and stocking requirements for white fish and predatory fish. It is also important to mention that the growth of certain indigenous fish species in natural waters is no longer at a level that ensures their survival, due to the load caused by over-fishing and lack of the spawning sites, so they need to be settled.

In certain waters, it is necessary to adapt to changing environment as a result of the succession processes and climate change.

Each water area has its specific characteristics, its ecological properties, and the head of the angling ponds must be adapted to it. However, a guide could help fish farmers in a great way to improve the efficiency of their production further.

By creating a new type of fish structure optimized for specific water areas, the ever-widening range of arguments can be scientifically substantiated, as a new type of fish structure - with special regard to whitefish stocks - can even increase fish production and, consequently, their earnings. The growing number of angler should be better (over 400,000 people) calls for a very large social layer. Next to the typical carp-centric fishing methods, nowadays the light tackle and spinning fishing methods becomes more and more popular. Meeting these requirements is an extremely difficult task which is a new challenge to the pisciculturists.

Main goals:

- My goal is to develop a breeding and production technology that is suitable for settlement of large quantities of white fish of appropriate length of (4$5 \mathrm{~cm}$ ). 
- Optimize the ratio of white fish in the fish structure, rearing with carp in fish ponds.

- The adaptation of fish cages (pond in pond) in Hungary, especially with bream species.

- Developing conditions for fish cage to rearing indigenous fish.

- Optimize fish structure according to different habitat in our country.

\section{LITERATURE OVERVIEW}

25-30 years ago, angler-oriented fish farming was not recognized as a professional term. Since then, the proportion of fishing and angling waters has been increasing. Angling waters, as their name suggests are used mainly by anglers. According to their needs, it is necessary to form the fish structure. Especially in the last half century the scale of human intervention has increased dramatically, which means that without active fisheries management there would be even less fishes in our waters. Without fisheries management, the rate of the invasive species in fish structure would be dominant and constantly increasing. Nowadays, scientific speakers at many international conferences are calling attention to the fact that without the fish stocking, done by the head of the angling ponds, the fish diversity in the waters would be pinched. With the increasing needs of anglers and its fulfilment, it can help to achieve higher income. This provides financial capital, which can be used for fish stocking, fish protection, and solving certain environmental problems. The previous income sources have been transformed. Because of the current laws, the main portion of the income is realized by fishing. The white fish population of ponds and rivers could be increased with induced spawning and rearing, done by the pisciculturist. The stocking of white fish was predominantly derived from the fisheries of the Tisza, Danube and Lake Balaton (Fürész et al., 2006).

When designing the fish structure of lakes, needs to be considered the characteristics of each species, as well as the characteristics of different water features (Hegyi and Lefler 2016). The important feature of the fauna, that it is constantly changing (Felföldy et al., 1996). The main criteria of the predatory fish stocking is the presence of a sufficient quality and size of fish feed (white fish). This also provides that the white fish stock is important (Hegyi and Lefler, 2016). The main criteria of the intensive, extensive and natural water fish farming is the presence of suitable fish species (Felföldy et al., 1996).

The carp mainly consumes zooplankton and zoobenthos, so they cannot fully exploit the biological production of the lakes. In order to fully exploit the production, it is necessary to settle different species for polyculture. By introducing new species, we can greatly increase the efficiency of production. Among our native fish species, the settlement of the tench (Tinca tinca) can be advantageous. The tench can be characterized by slower growth. The swamp and vegetation-rich areas are considered as preferable by tenches, but carp doesn't like this habitat. The stocking of the tench in such water areas can be advantageous. Due to the much more active feeding characteristics of the common carp in intensive fish farming, the tench falls under nutrional competition therefore its development can be extremely slow (Horváth et al., 2000).

From the $19^{\text {th }}$ century the regulation of the river has transformed the water system in Europe. The first aspect is flood protection. This causes ecological degradation (Horváth et al., 2000). Irrigation can also be potential source of contamination by plant protection residues, fertilizers and heavy metals, which also affect fish communities (Malherbe et al., 2016) as well as the correct operation of sewage treatment plants (Lakatos et al., 2014), in addition, it is important to decrease the water consumption (HTTP2). Ever since there are less and less available spawning areas. It causes rare appearance of reofil fishes, for example asp, ide, nase (Chondrostoma nasus) and barbus (Barbus barbus). Due to ecological, angling and economic reasons, it is important to regularly in fishing ponds (Horváth et al., 2000).

In order to achieve further increase in production, the settlement of predator fishes is also important. The predatory fish eat those fish species, which eat the same feed like the cyprinids In addition, they produce valuable fish meat and they are more and more popular fish species among anglers (Fürész et al., 2006). White fish, including bream (Abramis brama), plays an important role in the feeding of predatory fish, for example pike-perch (Sander lucioperca) (Horváth et al., 2013), and catfish (Silurus glanis) (Horváth et al., 2011).

In my research, the optimal ratio of the white fish in fish structure of angling ponds is investigated. White fish is a collective noun for bream species, including of some cyprinid species, like crucian carp (Carassius carssius), nase, asp and barbel. Previously it was considered as economically less valuable species. The crucian carp appears less and less in domestic waters (Demény and Müller, 2014). Ottó Herman (1887) already wrote about its significance and its importance in gastronomy.

The bream species have low value in a fish farm, but in fishing respects they have high economical value (Horváth et al., 2010). I would like to focus primarily on breeding these species. The most well-known and most important of these are the bream species, silver bream (Blicca bjoerkna), blue bream (Ballerus ballerus), white-eye bream (Abramis sapa), ide (Leuciscus idus), rudd (Scardinius erythrophthalmus) and roach (Rutilus rutilus) (Hegyi \& Lefler, 2016). Among Hungarian anglers the most important is the bream (Harka \& Szepesi, 2004), except in the case of excessive rippling and fast-flowing waters (Lajkó, 1999). Similarly to carp, it does bioturbation (Vásárhelyi, 1961). It prefers slow, low-lying sections of the rivers (Harka and Sallai, 2007). Its nutrition is similar to carp (Antos, 1981). I would like to highlight the role of the asp in cyprinids. It is sensitive to water quality. They can be found almost everywhere in our larger rivers and ponds (Pintér and Pócsi, 2012). The 
importance of certain species of fish is also reflected by the fact, that some of them are protected by specific prohibition period in their natural spawning season, or with length limits (HTTP1).

The aquaculture sector is growing world-wide, but in Europe it has been stagnant for a decade. In intensive recirculation system, fish of different species and age are raised up to the size range determined by the market demands (Csorbai et al., 2015). Their advantage over other technologies is that they can be cultured under almost completely controlled conditions, thus reducing environmental load (Davidson et al., 2015; Good et al., 2016). The development of the intensive system also promoted the development of the fish feeding. Among the fish farming methods, we can achieve the best fish production using intensive system (Csorbai et al., 2015). In order to maximize the production level, the system should be designed according to the different biological needs of each species (Elalouf et al., 2017).

Aquaculture cage systems are not widespread in our country (Csorbai et al., 2015). Attention should be also paid to the reduction of aquatic plants growth. Natural waters may be particularly vulnerable during the pond filling. When designing the fish structure, it is important to emphasize the presence of the species of fish consuming macro-vegetations, such as carp density (Maucha et al., 1954). The various aquatic plants associations have different amount of zooplankton (Szító et al., 1997) and different water chemical quality parameters (Kiss et al., 2013). Different habitats have several fish structures (Erős et al., 2009).

\section{MATERIAL AND METHODS}

- As a preliminary experiment rearing of ide larvae in recirculation aquaculture system for 21 days.

- Culture of white fish in cage conditions. Due to the different environmental needs of different fish species, many parameters need to be investigated, for example: stocking density, feeding, oxygen level, monoculture or mixed populations, growth potential, mortality.

- Investigating the growth and survival of the reared fish under smaller pond conditions.

- Culture of white fish in mixed populations, in different fish structures.

- Fisheries experiment in a pond-to-pond system, with special attention to the white fish
- The pilot program would be set up through the extensive professional contacts of the Szent István University Department of Aquaculture or in fish farms or MOHOSZ organization.

\section{RESULTS AND DISCUSSION}

\section{Preliminary results}

Following the artificial spawning of ide, we have successfully rearing the larvae in recirculation aquaculture system (RAS) for 21 days. We stocked the larvae into $12 \mathrm{~L}$ tanks, with 25, 50, 75 and 100 larvae/L density. We investigated the effect of stocking density and survival ratio on growth. In case of different larvae density, different mortality values were obtained. The highest survival rate obtained in the $25 \mathrm{ind} / \mathrm{L}$ group with $86.8 \pm 4.9 \%$ and the lowest in 75 ind/L group with $75.7 \pm 7.2 \%$. There was no statistical differences between the results of different stocking density. The highest growth was established in group $75 \mathrm{ind} / \mathrm{L}$ (28.0 $\mathrm{mg} \pm 24)$ and lowest in group $50 \mathrm{ind} / \mathrm{L}(25.3 \pm \mathrm{mg} 33 \%)$. Expected results:

Determining and describing the optimal conditions and the critical points of white fish rearing in caged conditions. The investigation of applicability of technological innovation, and the quantitative value of white fish in cages.

Provision of information on the growth and survival of rearing white fish in smaller lakes. It turns out that the test is practicable for each species. Different production data will be generated in a different fish structure. Finding the optimal result.

Assessment of mixed populations of carp and white fish in the pond-to-pond system. The impact of the settlement structure on fish production. Presentation of the growth and survival results of different species of fish. Production of white fish stocks suitable for settle in fishing waters.

\section{ACKNOWLEDGEMENTS}

The publication was supported by the EFOP-3.6.3VEKOP-16-2017-00008 project and it is co-financed by the European Union and the European Social Fund. The work was supported by the European Fisheries Fund Fisheries Operative Programme III. axis, "European Fisheries Fund for Renewable Fisheries" provided by the EU and Hungary and by the MAHOP2.1.1-2016-2017-00002 (RESEARCHFISH) project.

\section{REFERENCES}

Antos, Z. (1981): Horgászok Kézikönyve, Mezőgazdasági kiadóMOHOSZ, Budapest

Csorbai, B.-Péteri, A.-Urbányi, B. (2015): Intenzív haltenyésztés. Váramédia-Print Kft., Gödöllő

Davidson, J.-May, T.-Good, C.-Waldrop, T.-Kenney, B.-Fyhn, T.Summerfelt, S. (2016): Production of market-size North American strain Atlantic salmon Salmo salar in a land-based recirculation aquaculture system using freshwater. In: Aquacultural Engineering, 74: 1-16 pp.
Demény, F.-Müller, T. (2014): Veszélyeztetett lápi halak megóvása (lápi póc, réti csík, széles kárász) SZIE megbízásából: Vármédia Print Kft., Gödöllö

Elalouf, H.-Kaspi, M.-Elalouf, A.-Halachmi, I. (2017): Optimal operation policy for a sustainable recirculation aquaculture system for ornamental fish: simulation and response surface methodology. In: Computers \& Operation Research

Erős, T.-Specziár, A.-Bíró, P. (2009): Assessing fish assemblages in reed habitats of a large shallow lake-A comparison between 
gillnetting and electric fishing. In: Fishceries Research 96(1): 70$76 \mathrm{pp}$.

Felföldy, L.-Gönczy, J.-Pintér, K.-Széky, P.-Tasnády, R.-Tölg, I. (1996): Halgazdálkodás I. MOHOSZ, Budapest

Fürész, Gy.-Dudás, T.-Zellei, Á. (2006): A halgazdálkodás gyakorlata. Magyar Országos Horgász Szövetség

Good, C.-Davidson, J.-Iwanowicz, L.-Meyer, M.-Dietze, J.-Kolpin D. W.-Marancik, D.-Birkett, J.-Williams, C.-Summerfelt, S. (2016): Investigating the influence of nitrate nitrogen on postsmolt Atlantic salmon Salmo salar reproductive physiology in freshwater recirculation aquaculture systems. In: Aquacultural Engineering, Available online 5 October 2016

Harka, Á.-Szepesi, Zs. (2004): Magyarország halfaunája. Nimfea Természetvédelmi Egyesület, Szarvas.

Harka, Á.-Sallai, Z. (2007): Magyarország halfaunája.

Hegyi, Á.-Lefler, K. K. (2016): Horgásztavak üzemeltetésének gyakorlata. Dr. Hegyi Árpád.

Herman, O. (1887): A magyar halászat könyve. Királyi Magyar Természettudományi Társulat, Budapest.

Horváth, L. (2010): Halbiológia és haltenyésztés. Mezőgazda kiadó.

Horváth, L.-Béres, B.-Urbányi, B. (2011): Ökológiai szemléletú tógazdálkodás Haltenyésztés hidrobiológiai alapokon, Szent István Egyetem, Környezet- és Tájgazdálkodási Intézet, Halgazdálkodási Tanszék

Horváth, L.-Urbányi, B.-Horváth, Á. (2011): A harcsa (Silurus glanis) biológiája és tenyésztése, Szent István Kiadó

Horváth, L.-Urbányi, B.-Horváth, Á. (2013): A süllő (Sander lucioperca) biológiája és tenyésztése, Sztárstúdió Bt., Gödöllő

Http1.: http://portal.nebih.gov.hu/documents/10182/808522/2017 +Fajlagos+tilalmi+id $\% \mathrm{C} 5 \% 91 \% 2 \mathrm{C}+\mathrm{m} \% \mathrm{C} 3 \% \mathrm{~A} 9$ rettartom $\% \mathrm{C} 3$ \%A1ny\%2C+kifoghat\%C3\%B3+darabsz\%C3\%A1 m.pdf/a046 1c3c-4b56-4951-8310-1d38a28e9e36 (download time: May 2017)
Http2: http://www.sciencedirect.com/science/article/pii/ 0025326X72901051(download time: May 2017)

Lajkó, I. (1999): Halászati alapismeretek, Agroinform: 61-73.

Lakatos, Gy.-Veres, Z.-Kundrát, J.-Mészáros, I. (2014): The management and development of constructed wetlands for treatment of petrochemical waste waters in Hungary: 35 years of experience. In: Ecohydrology \& Hydrobiology, 14(1): 83-88 pp.

Kiss, K. M.-Lakatos, Gy.-Borics, Gy.-Gidó, Zs.-Deák, Cs. (2003): Littoral macrophyte-periphyton complexes in two Hungarian shallow waters. Hydrobiologia 506-509: 541-548 pp.

Malherbe, W.-Wepener, J.-Vuren Van, J. H. J. (2016): The effect of large-scale irrigation scheme on the fish community structure and integrity of the subtropical river system in South Africa. Ecological Indicators 69: 533-539 pp.

Maucha, R.-Erős, P.-Donászy, E.-Jaczó, I.-Jászfalusi, L.-Papp, A.Veszprémi, B.-Woynárovich, E. (1954): Tógazdasági haltenyésztés a gyakorlatban. Mezőgazdasági kiadó, Budapest.

Pintér, K.-Pócsi, L. (2002): Hal. Mezőgazda kiadó, Budapest

Szilágyi, M. (1995): A tiszai halászat - Eszközök és fogási módok történeti változásai. Akadémiai Kiadó, Budapest.

Szító, A.-Zsuga, K.-Bancsi, I.-Kovács, P.-Végvári, P. (1997): A hínár- és mocsári vegetáció haltáplálék-készletének vizsgálata a Kiskörei-víztározóban. Halászat 90: 34-42 p.

Vásárhelyi, I. (1961): Magyarország halai írásban és képekben. Borsodi Szemle Könyvtára, Tudományos Ismeretterjesztő Társulat Borsod megyei Szervezete és az Északmagyarországi Horgász Egyesület, Miskolc 